\title{
THE ANALYSIS OF SUPPORT FOR INNOVATIVE LABOR IN UKRAINE
}

\author{
Anna Chernoivanova \\ Department of Management and Business \\ Simon Kuznets Kharkiv National University of Economics \\ 9a Nauky ave., Kharkiv, Ukraine, 61166 \\ anna1213ch@mail.ru
}

\begin{abstract}
Based on the results of analysis of managerial personnel in Ukraine the paper reveals last changes in application of advanced support technologies for managerial labor differentiated by the type of innovative activity, such as brainstorming, middle creative tasks and routine operations. Conducted age analyses for $\mathrm{PhD}$ personnel allowed to state and justify the age margins of their most productive innovative activity, so the paper proposes and grounds the advanced methodological approach to the support of innovation labor and its analysis. The paper also analyses the distribution of research and development spending in Ukraine by the sources of financing, dynamics of scientific personnel during the period 2010-2014, changes of scientific experts share in general population and trends in development of managerial personnel. In conclusion peculiarities of advanced methods in application for personnel innovative activity were proposed and justified; demographic characteristics of innovative labor (age, education and so on) and also the sources of its financing were analyzed; the features of innovative labor at macro- and meso-level (country, education and so on were analyzed); characteristics of innovative labor itself (the level of its creativity, innovation) were determined; it was offered to differentiate the composition of stages and their content in correspondence to: branch specificity, type of innovative labor and the level of innovation of labor itself; the general number of scientific workers, the numbers of doctors and candidate of sciences, who carry out scientific-technical works, were compared.
\end{abstract}

Keywords: innovative labor, demographic analysis, innovational activity, brainstorming, routine operations, research staff.

\section{Introduction}

Finding solutions for ensuring the efficient application of regulating mechanisms for social and demographic processes in the field of innovation activity may be defined as priority task for researches intended on the further promotion of social and economic development in Ukraine.

The current stage of socio-demographic processes in Ukraine and restoration of scientific and technological capacity require development of new organizational and economic mechanisms of innovation activity support in business. Also, this process is accelerated by information revolution that leads to a cascade innovations and complications of the nature of labor process.

At the same time the existent complicated situation in innovative labor of Ukraine conditions the necessity of further development and deepening of the studies in this direction. The analysis of the innovative labor support as an integral object needs the complex system approach that is also absent for today.

\section{The literary review}

The review of theoretical researches, done by Ukrainian and foreign scholars, shows gradual accumulation of scientific knowledge and practical experience in the problem solutions of organizational and economic support for personnel innovation activity. For example, in the work [1] it was underlined, that the economic growth is influenced by scientific-technical progress and knowledge. Then the famous American specialist in the management theory, the author of the work [2] also accented on intellectual leadership at using the labor potential of enterprise. Thus, the work [3] discusses the existing rationing methods of personnel innovation activity, their advantages, disadvantages and peculiarities. (Some authors [4] recommend the guidance on the innovative labor distribution that depends on the type of personnel innovation activity. The author of the work [5] shows the different estimation approaches to the justified number of administrative staff and highlights some features in the content of this employee category. The authors of the work [6] explore the problems of application of best foreign experience in organization of personnel innovation 
activity to the reality of Ukrainian business.The work [7] offers the combination of micro- and macroeconomic analysis that, according to the author, allows determine the concrete directions of innovative activity of enterprise and the country in whole. The work [8] considers the question of organization of managerial labor and its special features at metallurgical enterprises only. However, these studies did not identify a single approach to innovative labor and its analysis.

This argues for the urgency of development of the comprehensive methodological approach to the personnel innovation activity support and its demographic analysis, and together with some unresolved scientific and practical issues in this area justifies theme, purpose and main objectives of the research.

\section{Aim and tasks of research}

The purpose of the research is to justify the advanced methodological approach to innovative labor support and to develop the technique for its demographic analysis.

To achieve purpose the research has following scientific tasks:

1) to conduct demographic analysis of the current state, changes and development of management personnel;

2) to conduct age analyses for PhD personnel allowed to state and justify the age margins of their most productive innovative activity;

3) to reveal existing dynamics of created and advanced technologies by the type of innovative labor;

4) to analyze the support of innovative labor according to differentiation by the types of innovative works.

\section{Materials and Methods}

In the process of research the following general scientific and special methods were used: the method of statistical and mathematical analysis and also the methods of economic analysis such as table, comparative, index - for the study of the state of innovative labor and assessment of its results; regressive analysis - for revelation of the factors of influence on the efficiency of innovative labor; graphic method - for the visible presentation of the principles of analysis; logical generalization and complex approach - for grounding of methodological approach to analysis.

\section{Results of research}

On the basis of economic literature and data of State Statistics Service on economic security $[9,10]$ in the field of innovation work the detailed analysis of personnel innovation activity support was conducted, that resulted in the following conclusions.

Firstly, the total employee number of scientific organizations in Ukraine decreased each year during last 20 years. In 2014, the total number of research employees decreased by $11 \%$ compared to 2013 and amounted to 109.6 thousand. But in comparison with the year 2000 this number reduced in 1.72 times, in comparison with the year 1995 - in 2.67 times. Compared to 2005, the total number of scientific staff in 2014 decreased only by $35.8 \%$.

Scientific and technical employees group takes the major share in the total number of scientific organizations personnel (in 1995 its share was $60 \%$ in total number of researchers, in $2000-64.2 \%$, in $2005-61,8 \%$, in $2013-63.2 \%$, in $2014-63.3 \%$ ). For the period of 1995-2014 years the number of specialists who perform scientific and technical work significantly decreased: from 179.8 thousand to 69.4 thousand, or in 2.6 times. For example, compared with 1995 this decrease totaled to 110,400 people or $61.40 \%$. The decrease also gradually traced for 15 years. The decline of this parameter was partly due to the reduction of personnel with scientific degree (doctors and candidates of sciences). Therefore it is necessary to analyze the decline of this staff category.

Number of doctors who perform scientific and technical work has slightly increased in comparison with 2005 by 100 people, or $2 \%$, as compared to 1995 and by 200 people or $5 \%$, in comparison with 1995. It should also be noted that during 2010-2013 this number did not change stated at the level of 4,500 people. The number of candidates of science who perform scientific and 
technical work (ST) in comparison with 2005 decreased by 2,300 people or by $13.5 \%$. (in 2011 the decline totaled to $8.7 \%$, in $2013-7.5 \%$ ). It should also be noted that in 2005-2006 the number of candidates did not change and amounted to 17.0 thousand, as well as during the period of 2012-2013 it stated as 15.9 thousand. In contrast, the number of half day ST personnel (starting in 2010 it also includes all teaching staff of higher education institutions) tends to increase. Compared with 1995, this category increased each year, except the last 2011-2014. In 2011, a decrease of this parameter was negligible (1.7\%) compared to 2010. In 2012 the number of half day ST personnel decreased in comparison with the previous year by $10.4 \%$. In 2013 , respectively increased by only $6.5 \%$, but in 2014 this figure compared with 2013 had significant decrease by $15 \%$ (but compared to 1995 increased by $16.3 \%$ ).

As the number of specialists who perform scientific and technical work, occupy the largest share in the total number of scientific personnel, the number of all the experts, except half day employees, has the similar dynamics.

Secondly, the share of researchers in the total population is small (less than $0.5 \%$ ) and tends to decrease during the period of 2010-2014. As the Table 1 shows, in 2014 the academic staff share in the total population was only $0.26 \%$ at the lowest level during the recent years.

As the number of specialists who perform scientific and technical works occupies the largest share in the total number of scientific organizations employees, their share in the total population have similar dynamics.

Thirdly, total amount of spending to finance scientific and technical work grew until 2013, when it reached the highest level for decade at UAH 11,161.1 $\mathrm{mln}$. In 2014, total expenditures amounted to UAH 10,320.3 mln that was double spending for the year 2005, but less than 2013 spending by $7.5 \%$.

Table 1

A comparison of the number of scientific staff share in the general population for the years 2010-2014

\begin{tabular}{|c|c|c|c|c|c|c|c|}
\hline \multirow[t]{2}{*}{ Parameter } & \multirow[t]{2}{*}{2010} & \multirow[t]{2}{*}{2011} & \multirow[t]{2}{*}{2012} & \multirow[t]{2}{*}{2013} & \multirow[t]{2}{*}{2014} & \multicolumn{2}{|c|}{$\begin{array}{c}\text { Change in } \\
\text { comparison with, } \%\end{array}$} \\
\hline & & & & & & 2010 & 2013 \\
\hline $\begin{array}{c}\text { The share of the number of scientific organizations employees } \\
\text { in the general population, } \%\end{array}$ & 0,32 & 0,31 & 0,30 & 0,29 & 0,26 & $-0,06$ & $-0,03$ \\
\hline $\begin{array}{l}\text { The share of the number of professionals who carry out } \\
\text { scientific and technical work in general population, } \%\end{array}$ & 0,21 & 0,20 & 0,19 & 0,18 & 0.16 & $-0,05$ & $-0,02$ \\
\hline
\end{tabular}

Fig. 1 shows recent changes in distribution of research and development spending in Ukraine by the sources of financing.

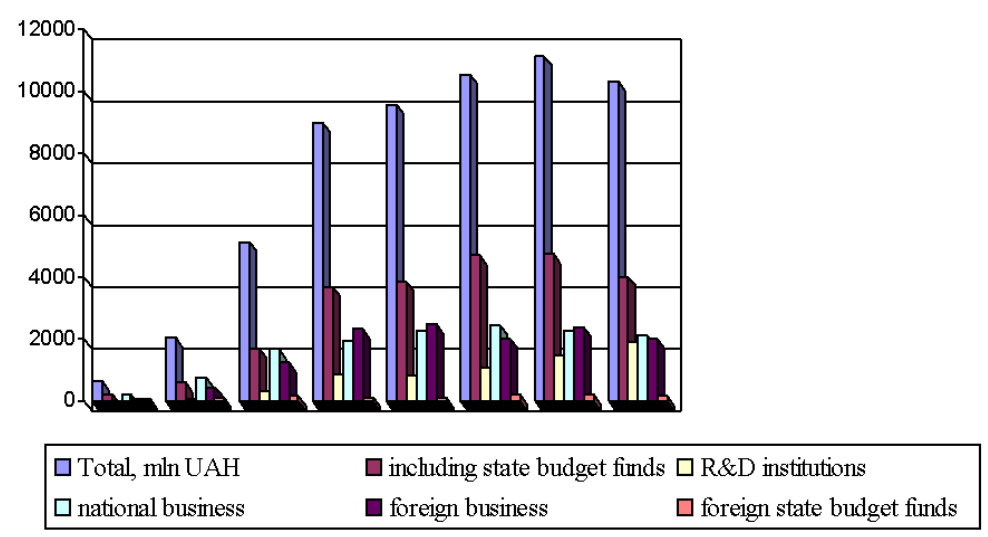

Fig. 1. Dynamics of distribution of research and development spending in Ukraine by the sources of financing

The primary source of funding for R\&D in Ukraine is the state budget funds. Their share in total expenditure amounted to $33.16 \%$ (in 2005) and to $39 \%$ (in 2014). The maximum 
amount of state budget funds was spent on R\&D in 2013 (4762.1 mln), in 2014 it amounted to only 4021 million.

The absolute amount of business research and development spending increased in 2013 compared with ten previous years, but its share in total funding decreased compared with 2005. In 2013, compared with the ten previous years the share of domestic companies significantly reduced. The share of foreign business in total spending in 2013 was $21.61 \%$, which is 1.4 times the share of foreign funds in 1995 and $2.46 \%$ less than in 2005. It should be noted that in 2012 the funds of foreign business declined over the previous year. In 2014, compared to the years 2000-2013 the share value of foreign state spending also declined.

The share of financing scientific and technical work by R\&D institutions increased significantly over the period $1995-2014$ (from $2.2 \%$ to $18.7 \%$ ).

Fourthly, analysis of the distribution of specialists with scientific degrees by age justifies the conclusion that methodological approach to support of innovation labor should be based on the most productive age framework. So it was revealed, that the most efficient for the innovation activity at doctors degree is the age of $41-70$ years, at $\mathrm{PhD}-31-50$ years. At this age, an individual is capable for deep thinking, thorough literature review, generating and grounding expert opinions based on received skills and abilities.

Fifthly, statistics, however, show that despite the existing complexity, Ukraine has maintained strong research capabilities. Number of doctors in Ukraine compared with 1995 increased 1.65 times (from 9,759 to 16,090). The number of candidates of sciences in comparison with 1995 demonstrated 1.5 times increase (from 57,610 to 86,230).

Sixthly, in 2010 the share of companies that implemented new technological processes in the total number of enterprises that implemented innovations amounted to $42.9 \%$, more than half of enterprises innovated in production process. This trend continued for four years (during 2011-2013 the number of the industrial enterprises that implemented production innovation increased). But in 2014 , the level of both indices started to fall. The share of enterprises that introduced new processes is $38 \%$ and $49.7 \%$ - enterprises mastered production innovation.

The structure of developed technologies in recent years 2013-2014 slightly changed, but for two years middle innovative implementations took the most substantial portion (in 2014 their number amounted to 122 units and represented $39.5 \%$ of the total). "Brainstorming" engaged the second place with the share of $24.3 \%$ in 2014 and $-23.4 \%$ in 2013. Routine operations had the lowest share of the total number of created advance technologies: 6.1\% and 8.2 \% in 2013 and 2014 respectively.

The structure of implemented new technologies in recent years 2013-2014 also changed slightly, middle innovative implementations took the most substantial portion (in 2014 their number amounted to 1962 units and represented $67.8 \%$ of the total). "Brainstorming" engaged the second place with the share of $11.2 \%$ in 2014 and $-17.5 \%$ in 2013 . Routine operations had the lowest share of the total number of created advance technologies: $7.6 \%$ and $12.2 \%$ in 2013 and 2014 respectively. However, it is worth to mention that in 2014 the total number of implementations of new technologies increased by $24.3 \%$ to 17,442 units. The growth was reasoned by the increase of low innovative implementations, so may be defined as one that had positive long term impact.

Seventhly, the analysis of whole number of new and advanced technologies by types for the years 2013-2014 gives reasons to conclude that the middle innovative implementations had the largest share, "brainstorm" innovations had middle share and advancements of routine operations had the smallest share.

Eighthly, the analysis of the number of innovational industrial enterprises by economic activity for the years 2013-2014 allows conclude that processing industry had the largest share (90\%), electricity \& gas supply industry had the second top share, water supply industry had the third top share and mining industry ended the rate-list of innovational industries.

\section{Discussion of the results of the study of the offered methodological approach to innovative labor support}

The offered methodological approach gives a possibility to establish the characteristics, on which base the profile of innovative study can be elaborated. Its advantages are: establishment of 
demographic characteristics of innovative labor; determination of characteristics of innovative labor itself; possibility to take into account the demographic, psychological and cross-cultural aspects.

The limitation of this approach is explained by the lack of statistical information and absence of the adequate statistical base for last years.

The offered scientific-practical elaborations can be used in industry, its machine-building branch, at the regional level at analysis and also at elaboration and introduction of concrete arrangements as to the raise of effectiveness of innovative activity and managerial labor.

The results of this research are the continuation of previously grounded methodological approach to the analysis of the state of innovative activity and development of innovative labor.

The future direction of the study in this subject field can be the elaboration of innovative labor profile.

So, in whole, the offered methodological method in generalized form includes the following stages:

- at the first stage the analysis of the features on innovative labor at macro- and meso-level (country, region, branch) was carried out;

- at the second stage demographic characteristics of innovative labor (age, education and so on) and also the sources of its financing were analyzed;

- at the third stage the characteristics of innovative labor itself (the level of its creativity, innovation) were determined.

The composition of stages of the offered methodological approach and their content can be differentiated in accordance to the branch specificity, type of innovative activity and level of innovation of the labor itself. It is also possible to take into account demographic and cross-cultural aspects.

\section{Conclusions}

As the result of conducted analysis of support for personnel innovative activity the following components of the proposed methodological approach may be formulated:

1. The demographic analysis of support for personnel innovative activity allows to reveal its specific features due to the nature of innovative labor.

2. The age analyses for innovative personnel allows to detect the age margins of most productive innovative activity.

3. The dynamic analysis of developed and implemented new technologies reflects differentiation by type of innovative labor.

4. The comprehensive analysis of support for personnel innovative activity responds to differentiation by type of innovative labor.

\section{References}

[1] Davenport, T. H., Prusak, L. (2004). Working Knowledge: How Organizations Manage What They Know. Harvard Business School Press, 330.

[2] Denison, E. F. (1986). Trends in American Economic Growth (1982-82). Washington, DS: Brookings Institution, 220.

[3] Bekleshov, V. K., Zavlin, P. N. (1989). Normirovanie v nauchno-tehnicheskih organizacijah. Moscow: ekonomika, 240.

[4] Yeromenko, V. O., Kovalenko, G. O., Ryzhykov, V. S. (2004). Osnovy normuvannya praci: navchalnyj posibnyk. Kramatorsk: DDMA, 252.

[5] Yadranskyj D. M. (2007). Teoretyko-metodychni zasady formuvannya yedynoyi systemy normuvannya praci v Ukrayini. Dnypropetrovsk: Monolit, 228.

[6] Dzyuba, S. G., Gajdaj, I. Yu. (2005). Normuvannya praci v vitchyznyanij i mizhnarodnij ekonomici. Doneczk: TOV «Yugo-Vostok», Ltd, 172.

[7] Yefremov O. S. (2012). Upravlinnya innovacijnym rozvytkom pidpryyemstva: aspekty metodologiyi. Lugansk: vyd-vo SNU im. V. Dalya, 504.

[8] Vasylenko, V. M., Moroz, O. S. (2006). Upravlencheskyj trud na metallurgycheskom predpryyatyy: organyzacyya, obosoblenye, motyvaciya. Doneczk: OOO «Yugo-Vostok, Ltd, 175.

[9] Zhuk, I. M. (Ed.) (2015). Derzhavna sluzhba statysty Ukrayiny. Statystychnyj zbirnyk «Regiony Ukrayiny», 1. Kyiv: TOV «Vydavnycztvo «Konsultant», 310.

[10] Zhuk, I. M. (Ed.) (2015). Derzhavna sluzhba statysty Ukrayiny. Statystychnyj zbirnyk «Regiony Ukrayiny». Vol. 2. Kyiv: TOV «Vydavnycztvo «Konsultant», 685. 